\title{
Yield loss and economic thresholds of yellow nutsedge in irrigated rice as a function of the onset of flood irrigation
}

\author{
Nixon da Rosa Westendorff (1*); Dirceu Agostinetto ( $\left.{ }^{2}\right)$; André da Rosa Ulguim ( $\left.{ }^{1}\right)$; \\ Lais Tessari Perboni ('); Bruno Moncks da Silva ( $\left.{ }^{2}\right)$ \\ (') Universidade Federal de Pelotas (UFPel), Programa de Pós-Graduação em Fitossanidade, Campus Capão do Leão, s/n, 96160-000 \\ Pelotas (RS), Brasil. \\ (2) UFPel, Departamento de Fitossanidade, 96160-000 Pelotas (RS), Brasil. \\ (*) Corresponding author: nwestendorff@gmail.com
}

Received: October 21, 2013; Accepted: December 12, 2013

\begin{abstract}
Yellow nutsedge (Cyperus esculentus) is adapted to flooding and reduces yield in irrigated rice. Information on the competitive ability of this weed with the crop and the size of the economic damage caused is lacking. Mathematical models quantify the damage to crops and support control decision-making. This study aimed to determine yield losses and economic thresholds (ET) of this weed in the culture according to weed population and time of onset of irrigation of the crop. The field study was conducted in the agricultural year of 2010/2011 in Pelotas/RS to evaluate the competitive ability of BRS Querência in competition with different population levels of yellow nutsedge and two periods of onset of flood irrigation (14 and 21 days after emergence). The hyperbolic model satisfactorily estimated yield losses caused by yellow nutsedge. Population of yellow nutsedge was the variable most fitted to the model. The delay of seven days for the beginning of rice irrigation causes decrease in competitive ability of BRS Querência, and based on the ET calculated to the price paid for rice, it is necessary between two and thirteen plants $\mathrm{m}^{-2}$ weed to justify the control in the first and second period of irrigation, respectively. Increases in yield, price paid for rice and control efficiency of the herbicide, besides reduction of costs of controlling promote reduction of ET of yellow nutsedge in rice crops, justifying the adoption of control measures even at smaller weed population.
\end{abstract}

Key words: Cyperus esculentus, Oryza sativa, rectangular hyperbole.

\section{Perdas de produtividade e níveis de dano econômico de tiririca-amarela em arroz irrigado em função do início da irrigação por inundação}

\begin{abstract}
Resumo
A tiririca-amarela (Cyperus esculentus) é adaptada ao alagamento e causa redução de produtividade do arroz irrigado. Informações da habilidade competitiva da planta daninha com a cultura e a dimensão do prejuízo econômico por ela causado são escassas. Modelos matemáticos quantificam prejuízos às culturas e subsidiam a tomada de decisão de controle. O objetivo deste estudo foi determinar perdas de produtividade e níveis de dano econômico (NDE) da tiririca-amarela na cultura em função da população da planta daninha e da época de início da irrigação da cultura. Foi conduzido estudo a campo, na safra 2010/2011, no município de Pelotas, RS, para avaliar a habilidade competitiva da cultivar de arroz BRS Querência em competição com diferentes níveis populacionais de tiririca-amarela em duas épocas de início de irrigação da cultura (14 e 21 dias após a emergência). 0 modelo hiperbólico estimou satisfatoriamente as perdas de produtividade que a tiririca-amarela causa à cultura. A variável mais ajustada ao modelo foi a população de tiririca-amarela. O atraso de sete dias no início da irrigação do arroz causa decréscimo na habilidade competitiva da cultivar BRS Querência, sendo necessárias, com base nos NDE calculados à variável preço pago pelo arroz, entre duas e 13 plantas $\mathrm{m}^{-2}$ da planta daninha para justificar o controle na primeira e segunda épocas de irrigação, respectivamente. Aumentos da produtividade, preço pago pelo arroz e eficiência de controle do herbicida e a diminuição do custo de controle promovem redução nos NDE de tiririca-amarela na cultura, justificando adoção de medidas de controle sob menor população da planta daninha.
\end{abstract}

Palavras-chave: Cyperus esculentus, Oryza sativa, hipérbole retangular. 


\section{INTRODUCTION}

Rice is the most consumed cereal, and after maize, the most cultivated worldwide, occupying in the last decade an average area of 163.4 million hectares per year, with Brazil being the largest producer outside Asia (FAO, 2012). Weed serve as host for pests, reduce product quality and cause decreased commercial value of the cultivated area, and the competition for environmental resources imposed to crops is included among the factors that cause a decrease in productivity (Agostinetto et al., 2011; Fleck et al., 2008).

Among the sedge species, Cyperus esculentus is better adapted to humid lowlands, with almost exclusively vegetative propagation, complicating its control and interfering directly or indirectly with the productivity of rice (Buzsáki et al., 2008). Aiming to increase the competitiveness of crops against weeds, crop management practices such as flood irrigation, have been used effectively (Andres et al., 2007).

Empirical mathematical models such as the hyperbolic derivative (Cousens, 1985) have, through simulation of competition, the ability to predict, at early stages in certain situations, the loss of yield and, therefore, the reduction in final yield of cultures (Agostinetto et al., 2004). Based on explanatory variables as plant population, the models quantify the dry matter of shoots and soil cover, the relationship between the loss of crop yield and the final weed infestation. In this way, studies have been developed to predict the losses caused by weeds in several crops of economic interest, including irrigated rice (Agostinetto et al., 2005; 2007; Galon et al., 2007; Mamun et al., 2013).

Given the above, this study hypothesized that the earlier onset of flood irrigation increases the competitive ability of the rice cultivar BRS Querência against yellow nutsedge, and therefore increases the ET of weed to the culture, and the data generated by the study fit to the nonlinear regression model derived from the rectangular hyperbola. The goal of this study was to determine yield loss and economic thresholds of yellow nutsedge in the early-maturing cultivar BRS Querência, depending on the weed population, and different times of onset of flood irrigation.

\section{MATERIAL AND METHODS}

The field study was conducted in a completely randomized design in the agricultural year of 2010/2011 in Pelotas, state of Rio Grande do Sul. The treatments were a factorial arrangement of two irrigation periods (14 and 21 days after emergence (DAE)) and ten and eleven weed populations for the first and second irrigation period, respectively. For the first irrigation time (14 DAE), the levels of the weed factor were: 0 (four controls), 36, 56, 64, 92, 104, 188, 224, 344 , and 356 plants of nutsedge-yellow $\mathrm{m}^{-2}$. For the second irrigation time (21 DAE), the levels of the competitor were: 0 (four controls), 284, 300, 320, 356, 372, 448, 496, 520, 548 and 996 plants of nutsedge-yellow $\mathrm{m}^{-2}$. The populations of the weed were established at seven DAE of the crop.

Each experimental unit had $7.65 \mathrm{~m}^{2}$ area $(5.0 \mathrm{~m} \times 1.53 \mathrm{~m})$ with nine rice rows spaced $0.17 \mathrm{~m}$ apart. The area was prepared by using conventional tillage with plowing, harrowing and leveling. The experimental area is classified as Planossolo Hidromórfico Eutrófico solódico, belonging to the mapping unit Pelotas (EMBRAPA, 2009). The correction of soil fertility was based on soil analysis, as recommended for irrigated rice (SOSBAI, 2010).

The rice cultivar BRS Querência was sown in seed density of $103 \mathrm{~kg} \mathrm{ha}^{-1}$, which resulted in final population of 380 viable rice plants $\mathrm{m}^{-2}$. The crop emergence occurred on $3 / 12 / 2010$. The nitrogen topdressing $\left(72 \mathrm{~kg} \mathrm{~N} \mathrm{ha}^{-1}\right)$ was split into two periods: half the dose was applied immediately before the first irrigation period and half applied at the differentiation of the panicle of rice. The flood irrigation of the experimental area was performed according to the levels of the irrigation treatment.

The control of the yellow nutsedge population and of other weeds in the experimental units was performed by herbicides on the seventh DAE. To control the species of the family Poaceae, the herbicide Clincher ${ }^{\circledR}$ (cyhalofop-butyl) was applied at a dose of $1.5 \mathrm{~L} \mathrm{ha}^{-1}$ plus Veget $\mathrm{Oil}^{\circledR}$ at $1 \mathrm{~L} \mathrm{ha}^{-1}$. For sedge plants exceeding the desired population levels and other broad-leaved species, the herbicide Basagran ${ }^{\circledR}$ 600 (bentazon) was used at a dose of $1.6 \mathrm{~L} \mathrm{ha}^{-1}$ added of mineral oil Assist ${ }^{\circledR}$ at $0.5 \% \mathrm{v} / \mathrm{v}$. For the establishment of yellow nutsedge populations, the plants were previously protected with plastic cups or brown paper boards depending on the desired population, so that were not affected by the herbicide.

The variables assessed at $25 \mathrm{DAE}$ were: plant population (PP), dry matter of shoots of the weed (DMS) and soil cover promoted by the weed (SC). Quantification of PP was performed by counting the individuals by averaging the two areas of $0.25 \mathrm{~m}^{2}(0.5 \mathrm{~m} \times 0.5 \mathrm{~m})$ in each experimental unit. To determine the DMS, C. esculentus plants were collected in an area of $0.25 \mathrm{~m}^{2}(0.5 \mathrm{~m} \times 0.5 \mathrm{~m})$ which were later oven dried at a constant temperature of $60^{\circ} \mathrm{C}$ to constant weight. $\mathrm{SC}$ was determined by visual assessment, using the means of two raters.

To determine grain yield, the useful area of each experimental unit $\left(3 \mathrm{~m}^{2}\right)$ was harvested when the grain moisture content reached about $22 \%$. After weighing, grain moisture was determined, and the values were corrected for $13 \%$ humidity content. From the data of grain yield we calculated the percentage losses in relation to plots kept uninfested (control), according to the equation:

Loss $(\%)=[(R a-R b) / R a] \times 100$ 
In which: $R a$ and $R b$ are productivities of the crop without and with the presence of yellow nutsedge, respectively. The values of dry matter of shoots $\left(\mathrm{g} \mathrm{m}^{-2}\right)$ and of soil cover (\%) were previously multiplied by 100 , thus avoiding the need to correct these values in the model (Agostinetto et al., 2004; Fleck et al., 2004; Galon et al., 2007).

The relationship between percent yield loss in rice $(\mathrm{Yl})$, according to the explanatory variables PP, DMS and SC was calculated using the model derived from nonlinear hyperbolic regression, as proposed by Cousens (1985):

$\mathrm{Yl}=[(i \times X) /(1+(i / a) \times X)]$

where: $\mathrm{Yl}=$ yield loss (\%); $X=$ explanatory variables $\mathrm{PP}$, DMS or SC; $i$ and $a=$ yield loss (\%) per plant of yellow nutsedge when the value of the variable approaches zero or when tends to infinity, respectively.

To calculate the economic threshold (ET) it was used the estimates of the parameter $i$, obtained from equation 2 (Cousens, 1985), and the equation adapted from Lindquist and Kropff (1996):

$\mathrm{ET}=[C c /(P \times R \times(i / 100) \times(H / 100))]$

where: $\mathrm{ET}=$ economic threshold (plants of yellow nutsedge $\mathrm{m}^{-2}$ ); $C c=$ costs of controlling (herbicide and application, in dollars ha $\left.{ }^{-1}\right) ; P=$ price of rice (dollars $\mathrm{kg}^{-1}$ grains); $R=$ rice grain yield $\left(\mathrm{kg} \mathrm{ha}^{-1}\right) ; i=$ rice yield loss (\%) per unit of weed when the population approaches zero and $H=$ level of herbicide efficiency (\%).

Three values were estimated for the variables $C c, P, R$ and $H$ (Equation 3). Thus, for costs of controlling $(C c)$ we considered the average value of 54.3 dollars ha ${ }^{-1}\left(1.6 \mathrm{~L} \mathrm{ha}^{-1}\right.$ of Basagran ${ }^{\circledR} 600+$ mineral oil Assist ${ }^{\circledR}$ at $0.5 \% \mathrm{v} / \mathrm{v}+$ cost of aerial application ha ${ }^{-1}$ of the product in Pelotas (RS) in the crop year 2010/2011), and the minimum and maximum costs vary by $\pm 30 \%$ compared to the average cost. Prices $(P)$ were obtained from the lowest (US\$ 7.50), average (US\$ 12.40) and the highest value (US\$21.00) paid in U.S. dollars for the $50 \mathrm{~kg}$ bag of paddy rice in the RS in the last 7 years (IRGA, 2011a). The rice yield $(R)$ was based on the lowest $\left(5630 \mathrm{~kg} \mathrm{ha}^{-1}\right)$, medium $\left(6665 \mathrm{~kg} \mathrm{ha}^{-1}\right)$ and highest average yield of rice $\left(7700 \mathrm{~kg} \mathrm{ha}^{-1}\right)$ obtained in the RS in the last 10 years (CONAB, 2011; IRGA, 2011b). The values of control efficiency of the herbicide $(H)$ were established in the order of 80,90 and $100 \%$ control, and $80 \%$ is the minimum acceptable level of weed control promoted by the herbicide (SOSBAI, 2010). For calculations of each variable referring to ET it was set average values (intermediate) of the variables related to the equation 3 that were not the target calculation.

The Gauss-Newton method was used to fit the data to the model, which by successive iterations estimates values of the parameters in which the sum of the squares of the deviations of the observations, in relation to the fitted values, is minimal (Ratkowsky, 1983). The value of the F statistics $(p \leq 0.05)$ was used as a criterion to analyze the data to the model. The acceptance criterion for fitting the data to the model was based on the highest coefficient of determination $\left(R^{2}\right)$ and the lowest value of the residual mean square (RMS).

\section{RESULTS AND DISCUSSION}

The values of the $F$ statistics were significant for all variables and satisfactory fits to the regression model derived from hyperbole were achieved, evidenced by the high coefficients of determination $\left(\mathrm{R}^{2}\right)$. Independent of the variable analyzed, the values obtained for the parameter $i$ increased when delayed the irrigation from 14 to $21 \mathrm{DAE}$, showing that there is on average $51 \%$ decrease in competitive ability of BRS Querência with the delay of irrigation (Figure 1).

The parameter $i$ was yield loss per unit weed of 0.45 , 0.04 , and $0.013 \%$ for PP, SC and DMS, respectively, when irrigation was started at 14 DAE (Figure 1a,c-e). For the second irrigation period (21 DAE), the parameter showed yield losses of $0.88,0.11$, and $0.034 \%$, considering the same order of variables (Figure 1b,d-f).

The earlier entry of water into the crop also favored the competitive ability of BRS-Pelota cultivar, in relation to barnyardgrass. In this case, the delay in irrigation from 1 to 10 and 20 days after herbicide application caused yield losses in the order of 24 and 34\%, respectively (Agostinetto et al., 2007). In another situation, the anticipated irrigation from 30 to 15 and $1 \mathrm{DAE}$ of rice without using herbicide, increased the yield of the cultivar Qualimax1 by 100 and $118 \%$, respectively, when competing with Cyperus esculentus and Echinochloa spp. (Agostinetto et al., 2011). The anticipation of irrigation in irrigated rice crop provides greater development and establishment of plants in the crop, reducing interference and losses caused by weeds (Carlesso et al., 1998).

The values of the parameter $i$ showed low competitive potential of yellow nutsedge against the cultivar tested according to the irrigation time (Figure 1). In a study with barnyardgrass, based on the parameter $i$, were observed yield losses of $8.4,10.4$ and $11.3 \%$ when irrigation was performed 1,10 and 20 after herbicide application, respectively (Agostinetto et al., 2007).

The parameter $a$, for all variables, has overestimated the asymptote, being necessary to restrict its value at $100 \%$ in all cases studied (Figure 1). This may have occurred because of the reduced competitiveness of the weed at low populations, or due to populations of the weed that occurred in the first irrigation time (14 DAE) of the study were not high enough to estimate the maximum yield loss (Agostinetto et al., 2004). For obtaining reliable estimate of the parameter, studies must rely on sufficiently high populations, even though they often do not represent the reality of crops (Cousens, 1991). Thus, as adopted in other studies, the value of the asymptote was set at $100 \%$, assuming that restriction of maximum 

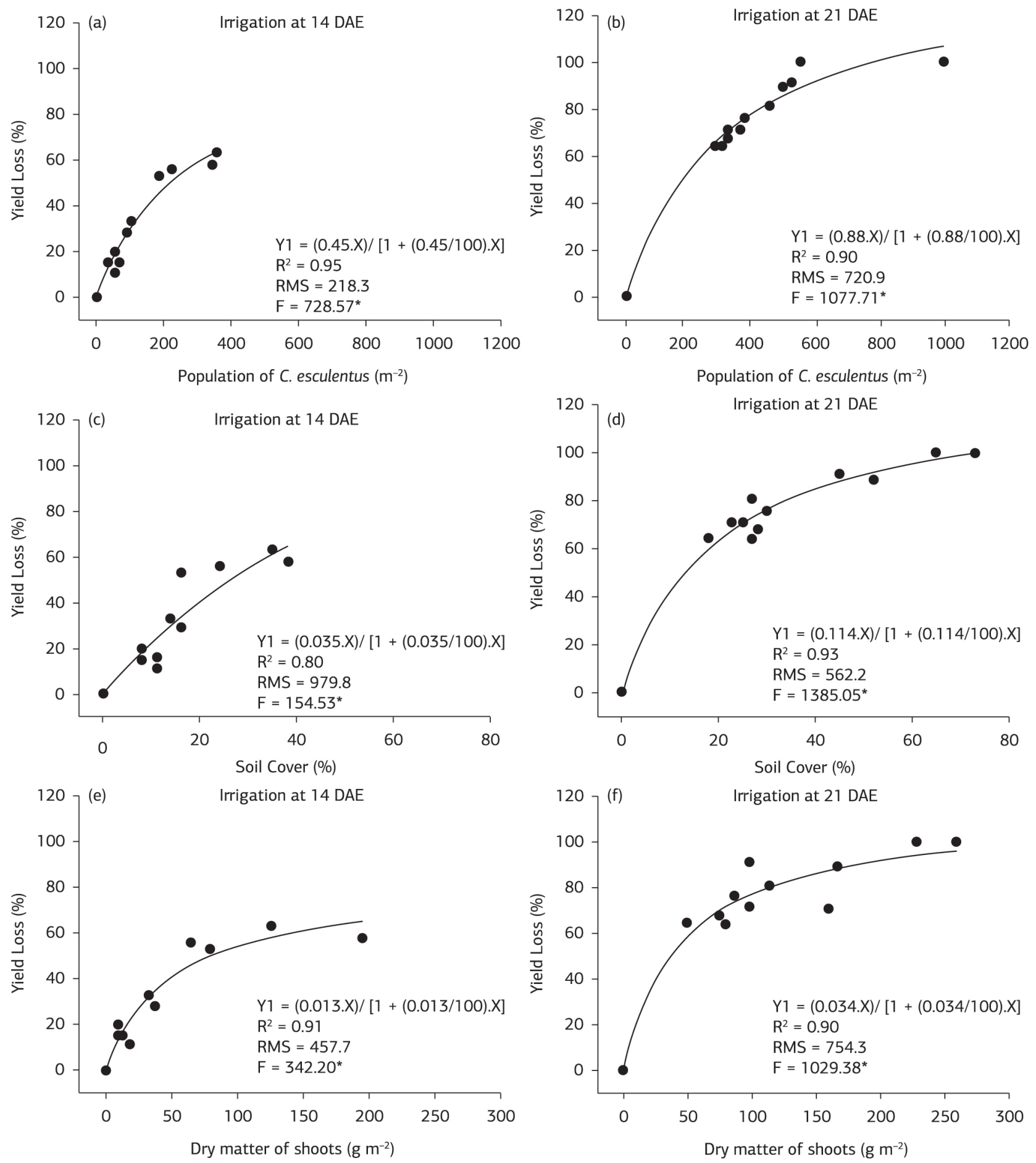

Figure 1. Yield loss (Pp) of the rice cultivar BRS Querência according to two irrigation periods (14 and 21 DAE), population levels, cover of soil per shoots and dry matter of shoots of Cyperus esculentus, 2010/2011. DAE: days after emergence; $\mathrm{R}^{2}$ : Coefficient of determination; RMS: residual mean square; *Significant at $5 \%$ probability.

loss, because there is no biological explanation for losses exceeding this (Agostinetto et al., 2004; Fleck et al., 2004).

The best fit of the data to the model was verified for the variable PP (Figure 1a,b). There was a satisfactory fit of the variables SC and DMS to the model $\left(\mathrm{R}^{2} \geq 80 \%\right)$, so these could also be used in decision-making to control yellow nutsedge in irrigated rice (Figures $1 \mathrm{c}-\mathrm{f}$ ), however, the variable weed population is easiest to use for this intended purpose. A study on the competitiveness of barnyardgrass with rice cultivar BRS Pelota, depending on the irrigation 
period, also found better fit of the variable weed population to the model, compared with dry matter of shoots, leaf area and soil cover (Agostinetto et al., 2007).

Considering the average grain yield of irrigated rice in Rio Grande do Sul at $7.700 \mathrm{~kg} \mathrm{ha}^{-1}$ (CONAB, 2011; IRGA, 2011a), the average price of 12.4 dollars paid per $50 \mathrm{~kg}$ bag (Banco Central do Brasil, 2011; IRGA 2011b) and the costs of controlling nutsedge-yellow at 54.3 dollars ha $^{-1}$, we estimated that the cost of its control would amount to $2.84 \%$ of the yield of irrigated rice. Therefore, based on the best fit of the observed data to the regression model for the $\mathrm{PP}$ variable and yield losses per plant of yellow nutsedge of 0.45 and $0.88 \%$ (parameter $i$ ), when irrigation was performed at 14 and $21 \mathrm{DAE}$, respectively, were found to be necessary, in the simulated variables: costs of controlling, yield and price paid for rice, six plants $\mathrm{m}^{-2}$ to justify the control if irrigation is performed earlier and only three plants $\mathrm{m}^{-2}$ when irrigation is held at $21 \mathrm{DAE}$.

A two year-study in Asia with a mix of weeds with predominance of around $80 \%$ of Scirpus maritimus and Cyperus difformis observed the need to have on average 5 and 7 weeds $\mathrm{m}^{-2}$ in the first and second year of cultivation, respectively, to justify the control, considering a yield of 5 tons of grain ha $\mathrm{h}^{-1}$, control cost of U\$ $30.00 \mathrm{ha}^{-1}$ and the remuneration of $U \$ 10.50$ per $50 \mathrm{~kg}$ bag of rice (Mamun et al., 2013).

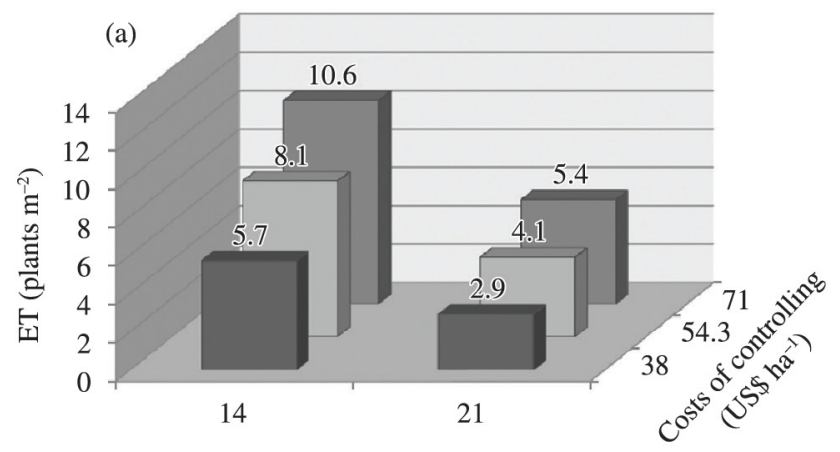

Onsent of irrigation in days after emergence of rice (DAE)

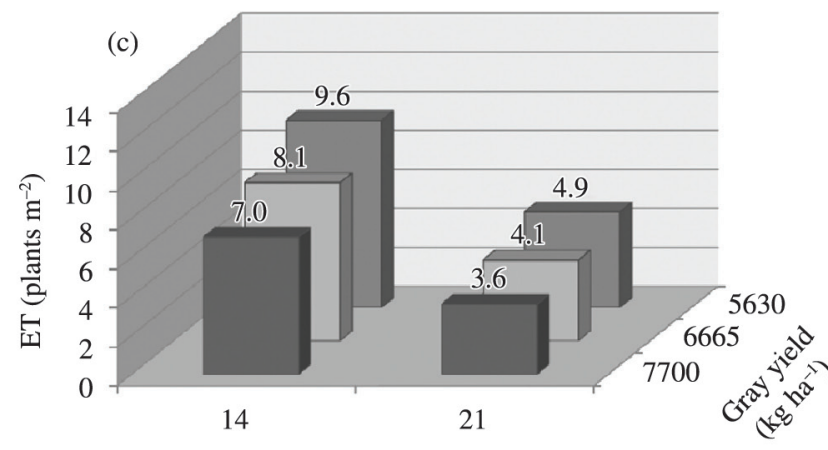

Onsent of irrigation in days after emergence of rice (DAE)
The values of the parameter $i$ obtained by the hyperbolic regression model for the variable PP, were 0.45 and 0.88 , when irrigation was performed at 14 and $21 \mathrm{DAE}$, respectively (Table 1). The delay in irrigation from 14 to $21 \mathrm{DAE}$ provided an increase of approximately $95 \%$ in the parameter $i$, demonstrating a decrease in competitive ability of the rice cultivar BRS Querência with delayed irrigation. The water depth is an important tool in the integrated weed management because, besides favoring the action of herbicides (Andres et al., 2007), acts as a physical barrier against the emergence of new weeds (Agostinetto et al., 2011). In this context, the delay in irrigation promoted the recovery of phytotoxicity of yellow nutsedge plants, caused by the application of the herbicide bentazon, and also a new flow of germination and establishment of weed in planted area, reducing the competitive ability of the crop.

ET values ranged from 4.8 to 13.4 yellow nutsedge plants $\mathrm{m}^{-2}$, considering the irrigation onset at $14 \mathrm{DAE}$, and 2.4 to 6.9 yellow nutsedge $\mathrm{m}^{-2}$ when irrigation started after 21 DAE. For all simulations performed, there was a decrease of ET when irrigation was delayed by seven days (Figures 2a-d).

Regarding the means of the minor or major values of simulated variables to obtain the ET, these occupied a range from 6.2 to 10.7 yellow nutsedge plants $\mathrm{m}^{-2}$ for irrigation started at $14 \mathrm{DAE}$, which resulted into losses of 2.79 and

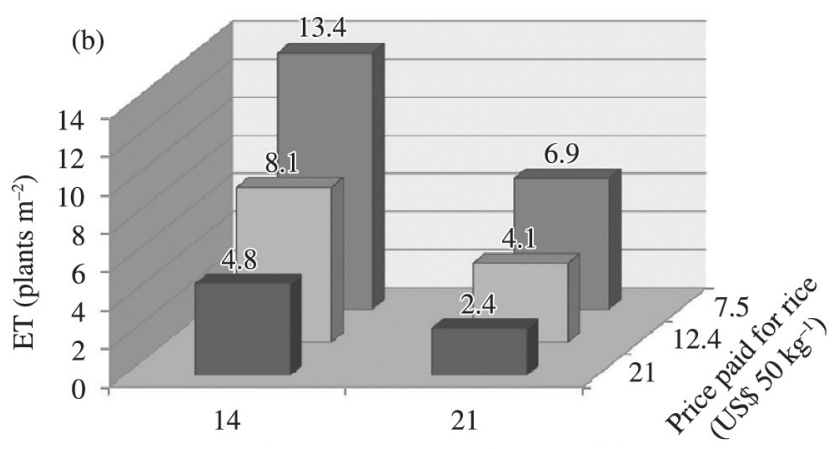

Onsent of irrigation in days after emergence of rice (DAE)

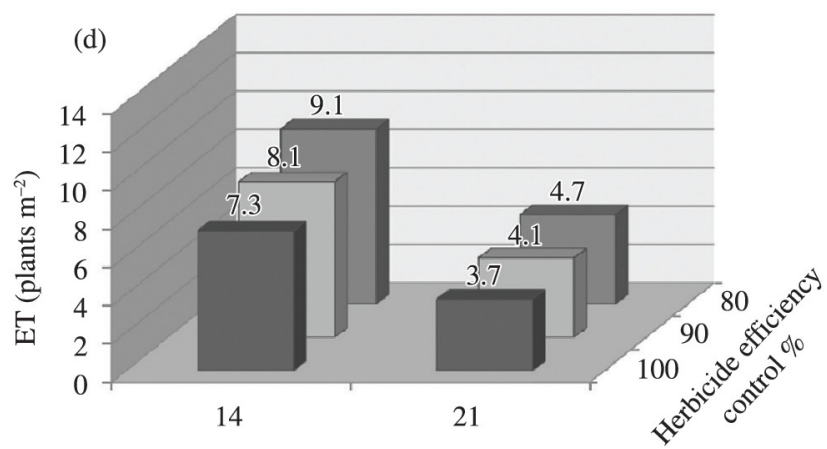

Onsent of irrigation in days after emergence of rice (DAE)

Figure 2. Economic thresholds (ET) of Cyperus esculentus, for the irrigated rice cultivar BRS Querência, according to estimates of costs of controlling weed, price paid for $50 \mathrm{~kg}$ bag of paddy rice, grain yield, control efficiency of the herbicide and irrigation periods, $2010 / 2011$. 
Table 1. Yield loss of the rice cultivar BRS Querência as a function of populations of Cyperus esculentus $\left(\mathrm{m}^{-2}\right)$ and two irrigation periods, 2010/2011

\begin{tabular}{|cccc|}
\hline Irrigation (DAE') & Yield loss (\%) & $\mathbf{R}^{\mathbf{2}}$ & $\mathbf{F}^{\mathbf{*}}$ \\
\hline 14 & $(0.45 . X) /[1+(0.45 / 100) . X]$ & 0.95 & 728.57 \\
\hline 21 & $(0.88 . X) /[1+(0.88 / 100) . X]$ & 0.90 & 1077.71 \\
\hline
\end{tabular}

'days after emergence. ${ }^{2}$ Value obtained by the hyperbolic regression model (Cousens, 1985). * Significant at 5\% probability

$4.82 \%$ in crop yield for the lowest and highest value of ET respectively. As for the second irrigation period (21 DAE), the mean values of ET were from 3.2 to 5.5 yellow nutsedge plants $\mathrm{m}^{-2}$, which caused a similar decrease of 2.82 and $4.84 \%$ for the lowest and highest ET value, respectively. The reduction in ET, with similar reduction in yield, is due to sharp decline in the competitive ability of BRS Querência with delayed flood irrigation.

As a result, ET for irrigation started at $21 \mathrm{DAE}$ was about $50 \%$ lower than those obtained for earlier irrigation. Therefore, when applied flood irrigation at 21 DAE becomes more urgent to implement measures to control yellow nutsedge on irrigated rice.

Analyzing separately the variables simulated, for the average of the two irrigation periods (14 and $21 \mathrm{DAE}$ ), the variation in ET was in the order of $87 \%$ for the variable costs of controlling (Figure 2a); 180\% for the variable price paid for rice (Figure $2 \mathrm{~b}$ ), 37\% for the variable rice yield (Figure 2c), and 25\% for the variable control efficiency of the herbicide (Figure 2d).

In a study to determine ET of barnyardgrass of the cultivar BRS Pelota, on the average of three irrigation periods $(1,10$, and 20 days after treatments (DAT)), were registered variations of $68 \%$ for the variable costs of controlling; $133 \%$ for the variable price paid, about $50 \%$ for the variable yield, and $25 \%$ for the control efficiency of cyhalofop-butyl herbicide (Galon et al., 2007).

Furthermore, taking into account the mean values of ET for the variables tested in each of the irrigation periods, the simulation showed a reduction of about $95 \%$ from the first to the second irrigation, regardless of the variable analyzed (Figure 2). Therefore, it is seen that the delay of seven days in the irrigation decreases almost by half the competitive potential of the cultivar BRS Querência with the weed studied. Consequently, there was a decrease of ET of yellow nutsedge in the crop, justifying an earlier control. For the cultivar Qualimax 1 were observed yield reductions of the order of 17 and 19\%, when it competed with yellow nutsedge and barnyardgrass and irrigation was delayed from 1 to 15 and 30 DAT, respectively, even when the herbicide penoxsulam was applied earlier (Agostinetto et al., 2011).

The delay in irrigation can provide a reduction in yield components of the crop and the possibility of emergence of new flows of weeds (Agostinetto et al., 2011), thereby enhancing the competitive niche overlap between species. In this context, management practices, such as early irrigation can be strategies more sustainable in the perspectives of environment, economics, protection and longevity of herbicide molecules and integrated management of weeds.

In relation to the intermediate values of each variable studied, the decreasing order of magnitude of ET of yellow nutsedge that will support decision-making of control are: price paid for harvested rice > cost of controlling weeds > grain yield of the crop $>$ control efficiency of the herbicide. Thus, it can be inferred that the price paid for rice represented the greatest impact on decision-making of control, and the control efficiency provided by the herbicide, less impact, under the studied conditions. Nevertheless, the variables price paid for the product and costs of controlling are difficult to be changed by farmers, so it is up to them to provide appropriate management practices to maximize yield and efficiency promoted by herbicide.

The economic threshold of yellow nutsedge (ET) in irrigated rice crops vary depending on the time of onset of flood irrigation of the rice crop. Moreover, anticipating the start of irrigation by seven days after crop emergence increases ET of weeds in rice culture, making it more flexible weed control. Besides that, the increases in grain yield, price paid for rice and control efficiency of the herbicide, and the reducing cost of weed control, promote reduction in ET of yellow nutsedge in irrigated rice crops justifying the adoption of control measures at smaller weed populations.

Examining the results of mathematical simulation, it is inferred, for example, that different crop managements, as the anticipation of irrigation for a period next to the adoption of control measures, has increased the competitive ability of the rice cultivar tested, being required between two and thirteen plants $\mathrm{m}^{-2}$ of weed to justify the control in the first and second irrigation period, respectively, according to the initial hypotheses. Therefore, it can be changed the time of decision-making of control and possibly the choice of herbicide molecules that have economic advantage and/or cause less environmental impact.

The cost of controlling, the environmental impacts of using herbicide and the possibility of intoxication of agents involved in its preparation and application can be minimized by the adoption of crop management practices that enable greater competitive potential of the crop against weeds, as the earlier irrigation.

\section{CONCLUSION}

The hyperbolic model satisfactorily estimates yield losses caused by yellow nutsedge to rice crops, and the explanatory variable plant population was the most fitted to that model, also confirming the initial hypothesis of the study. Moreover, the weed yellow nutsedge shows low competitive potential in irrigated rice crops, requiring at least considering the variable plant population and the first irrigation period, two units of weed $\mathrm{m}^{-2}$ to justify its control. 


\section{REFERENCES}

AGOSTINETTO, D.; FLECK, N.G.; RIZZARDI, M.A.; BALBINOT JUNIOR, A.A. Dano econômico como critério na decisão sobre manejo de genótipos de arroz concorrentes em arroz irrigado. Pesquisa Agropecuária Brasileira, v.40, p.1-9, 2005. http://dx.doi.org/10.1590/ S0100-204X2005000100001

AGOSTINETTO, D.; FLECK, N.G.; RIZZARDI, M.A.; BALBINOT JUNIOR, A.A. Perdas de rendimento de grãos na cultura de arroz irrigado em função da população de plantas e da época relativa de emergência de arroz-vermelho ou de seu genótipo simulador de infestação de arroz-vermelho. Planta Daninha, v.22, p.175-183, 2004. http://dx.doi.org/10.1590/S0100-83582004000200002

AGOSTINETTO, D.; GALON, L.; MORAES, P.V.D.; TIRONI, S.P.; DAL MAGRO, T.; VIGNOLO, G.K. Interferência de capimarroz (Echinochloa spp.) na cultura do arroz irrigado (Oryza sativa) em funçáo da época de irrigaçáo. Planta Daninha, v.25, p.689-696, 2007. http://dx.doi.org/10.1590/S0100-83582007000400005

AGOSTINETTO, D.; PANOZZO, L.E.; MORAES, P.V.D.; DAL MAGRO, T.; TAROUCO, C.P.; OLIVEIRA, C.; RUBIN, R. Épocas de aplicação de penoxsulam e de início da irrigação no arroz irrigado. Planta Daninha, v.29, p.405-412, 2011. http://dx.doi.org/10.1590/ S0100-83582011000200018

ANDRES, A.; FREITAS, G.D.; CONCENÇO, G.; MELO, P.T.B.S.; FERREIRA, F.A. Desempenho da cultivar de arroz BRS Pelota e controle de capim-arroz (Echinochloa spp.) submetidos a quatro épocas de entrada de água após a aplicação de doses reduzidas de herbicidas. Planta Daninha, v.25, p.859-867, 2007. http://dx.doi.org/10.1590/ S0100-83582007000400023

BANCO CENTRAL DO BRASIL. Dólar americano. Disponível em: <http://www4.bcb.gov.br/pec/taxas/batch/taxas.asp?id=txdolar>. Acesso em: 15 nov. 2011.

BUZSÁKI, K.; KAZINCZI, G.; BÉRES, I.; LEHOCZKY, E. The allelopathic effect of yellow nutsedge (Cyperus esculentus) on cultivated plants and common ragweed (Ambrosia artemisiffolia L.). Journal of Plant Diseases and Protection, v.21, p.327-331, 2008. Supplement.

CARLESSO, R.; HERNANDEZ, M.G.R.; RIGHES, A.A.; JADOSK, S.O. Índice de área foliar e altura de plantas de arroz submetidas a diferentes práticas de manejo. Revista Brasileira de Engenharia Agrícola e Ambiental, v.2, p.268-272, 1998.

COMPANHIA NACIONAL DE ABASTECIMENTO CONAB. Arroz. Comparativo de Área, Produtividade e Produção. Safras 2009/2010 e 2010/2011. Disponível em: <http://www.conab. gov.br/OlalaCMS/uploads/arquivos/11_09_19_09_49_47_boletim_ setembro-2011..pdf $>$. Acesso em: 22 set. 2011.

COUSENS, R.D. Aspects of the design and interpretation of competition (interference) experiments. Weed Technology, v.5, p.664-667, 1991.
COUSENS, R.D. An empirical model relating crop yield to weed and crop density and a statistical comparison with other models. Journal of Agricultural Sciences, v.105, p.513-521, 1985. http:// dx.doi.org/10.1017/S0021859600059396

EMPRESA BRASILEIRA DE PESQUISA AGROPECUÁRIA EMBRAPA. Centro Nacional de Pesquisa de Solos. Sistema brasileiro de classificaçáo de solos. 2.ed. Rio de Janeiro: Embrapa Solos, 2009. 412p.

FOOD AND AGRICULTURE ORGANIZATION OF THE UNITED NATIONS - FAO. Production of cereals and share in world (2012). Disponível em: <http://faostat.fao.org/site/339/default. aspx>. Acesso em: 9 dez. 2013.

FLECK, N.G.; AGOSTINETTO, D.; GALON, L.; SCHAEDLER, C.E. Competitividade relativa entre cultivares de arroz irrigado e biótipo de arroz-vermelho. Planta Daninha, v.26, p.101-111, 2008. http://dx.doi.org/10.1590/S0100-83582008000100011

FLECK, N.G.; AGOSTINETTO, D.; RIZZARDI, M.A.; BIANCHI, M.A.; MENEZES, V. G. Interferência de plantas concorrentes em arroz irrigado modificada por métodos culturais. Planta Daninha, v.22, p.19-28, 2004. http://dx.doi.org/10.1590/S0100-83582004000100003

GALON, L.; AGOSTINETTO, D.; MORAES, P.V.D.; DAL MAGRO, T.; PANOZZO, L.E.; BRANDOLT, R.R.; SANTOS, L.S. Níveis de dano econômico para decisão de controle de capim-arroz (Echinochloa spp.) em arroz irrigado (Oryza sativa). Planta Daninha, v.25, p.709718, 2007. http://dx.doi.org/10.1590/S0100-83582007000400007

INSTITUTO RIO-GRANDENSE DO ARROZ - IRGA. Séries históricas. IRGA, 2011a. Disponível em: <http://www.irga.rs.gov.br/ uploads/1318871736PRODARRS__serie_historica.pdf $>$. Acesso em: 25 set. 2011.

INSTITUTO RIO-GRANDENSE DO ARROZ - IRGA. Preços do arroz. IRGA, 2011b. Disponível em: <http://www.irga.rs.gov.br/ uploads/anexos/1321039486Precos_do_Arroz.pdf>. Acesso em: 15 nov. 2011.

LINDQUIST, J.L.; KROPFF, M.J. Applications of an ecophysiological model for irrigated rice (Oryza sativa) - Echinochloa competition. Weed Science, v.44, p.52-56, 1996.

MAMUN, A.A.; SHULTANA, R.; RANA, M.; MRIDHA, A.J. Economic threshold density of multi species weed for direct seeded rice. Asian Journal of Agriculture and Rural Development, v.3, p. 523-531, 2013.

RATKOWSKY, D.A. Nonlinear regression modeling: a unified practical approach. New York: Marcel Dekker, 1983. p.276.

SOCIEDADE SUL-BRASILEIRA DE ARROZ IRRIGADO SOSBAI. Arroz irrigado: Recomendaçōes técnicas da pesquisa para o sul do Brasil. Porto Alegre: Pallotti, 2010. 188p. 